CURRENT BIOCHEMISTRY

ISSN: $2355-7877$

Journal Homepage: http://biokimia.ipb.ac.id

Journal Email: current.biochemistry@ipb.ac.id

\title{
Immobilization of Lactobacillus plantarum B134 Cells using Sodium Alginate for Lactose Hydrolysis in UHT Milk
}

\author{
Lusiana Kresnawati Hartono ${ }^{1}$, Tatik Khusniati ${ }^{2}$, I Made Artika ${ }^{1}$, Sulistiani ${ }^{2}$, Abdul Choliq ${ }^{2}$ \\ ${ }^{1}$ Department of Biochemistry, Bogor Agricultural University (IPB), Bogor 16680, Indonesia \\ ${ }^{2}$ Research Center for Biology - Indonesian Institute of Sciences (LIPI), Bogor 16911, Indonesia
}

Received: 15 July 2014; Accepted 15 August 2014

*Corresponding author: Dr. Ir. Tatik Khusniati, M.App.Sc; Research Center for Biology - Indonesian Institute of Sciences (LIPI); Jalan Raya Jakarta-Bogor Km. 46, Cibinong, Bogor 16911, Indonesia, Telp. : +6281381686438 ; Email: tatikkhusni@yahoo.com

\section{ABSTRACT}

Hydrolysis of lactose in milk by $\beta$-galactosidase from immobilized bacterial cells has the potential to alleviate the problem of lactose intolerance. The present study was aimed to immobilize cells of L. plantarum strain B134 and evaluate their efficiency in hydrolyzing lactose in ultra high temperature (UHT) milk. Immobilized cells were generated by mixing cell suspensions with solutions of sodium alginate and calcium chloride. The $\beta$-galactosidase activity of the immobilized cells was tested by determining their ability in hydrolyzing lactose in UHT milk (whole milk and skimmed milk). Results showed that cells of L. plantarum strain B134 were entrapped optimally using a combination of $1 \%$ sodium alginate, $100 \mathrm{mM}$ calcium chloride and $12 \% \mathrm{w} / \mathrm{v}$ cell suspension. The highest $\beta$-galactosidase activity was achieved at $\mathrm{pH} 6.5$ and a temperature of $45^{\circ} \mathrm{C}$ for 5 minutes incubation time. The immobilization efficiency achieved was $28.95 \%$. The immobilized cells could reduce lactose by up to $85.45 \%$ in UHT whole milk and $91.26 \%$ in UHT skimmed milk. The times required for that reduction of lactose in UHT whole milk and UHT skimmed milk were 12 hours and 9 hours respectively. The immobilized cells could be re-used up to 4 times for efficient lactose hydrolysis for both types of milk. Therefore, immobilized cells of L. plantarum B134 have the potential to be used for lactose hydrolysis in UHT milk.

Keywords: Lactobacillus plantarum B134, cell immobilization, $\beta$-galactosidase, UHT Milk

\section{INTRODUCTION}

Milk is a nutritious diary product with a high level of nutrition. However, lactose intolerant individuals have insufficient amounts of $\beta$-D-galactosidase to digest lactose, a sugar found in milk. This causes discomfort in affected children and adolescents worldwide, causing abdominal pain, nausea, flatulence and bloating (Kishore and Kayastha 2012). Lactose intolerance is common occurred in people from 
Asia, Africa, the Middle East, the Mediterranean countries, as well as amongst Australian Aborigines (BPOM 2008). The enzymatic hydrolysis of lactose in milk and milk products by $\beta$-D-galactosidase alleviates the problem of lactose intolerance, which assist in the disposal of whey, and the problem of crystallization of lactose in different food products (Makkar et al. 1981).

A number of $\beta$-galactosidases have been studied for their potential application in the hydrolysis of lactose. The enzymes are essentially from yeast, fungal, and bacterial sources (Makkar et al. 1981). Lactic Acid Bacteria (LAB) are potential producers of $\beta$-galactosidase. Lactobacillus $\mathrm{sp}$. is one of the LAB often used in the production of fermented food products and beverages, hence its safety is guaranteed by generally regarded as safe (GRAS) (Sumanthy et al. 2012, FAO 2006). Lactobacillus bulgaricus was reported to have the ability to reduce lactose content up to 5060\% (Wierzbicki and Kosikowski 1973).

Enzymes are expensive to be discarded after a single use, which often makes their commercial exploitation uneconomic. This limitation can be addressed by the coupling of enzymes with a suitable support material using various immobilization techniques. Compared to soluble $\beta$-galactosidase, immobilized $\beta$-galactosidase may provide many advantages in the production of lactose reduced dairy products (Kishore and Kayastha 2012). Immobilized enzymes can be used repeatedly to manufacture products of good quality (Illanes et al. 2008). Research conducted by Grosova et al. (2009), Klein et al. (2013) showed that immobilized $\beta$-galactosidase can reduce levels of lactose in milk by up to $70 \%$.
Immobilization can also be performed on microbial cells which produce $\beta$-galactosidase. Microbes can produce $\beta$-galactosidase as intracellular or extracellular enzymes. Bacteria and yeast can produce $\beta$-galactosidase as intracellular enzymes while fungi produce it as extracellular enzymes (Panesar et al. 2010). Panesar (2007) reported that the lactose level in skimmed milk decreased to $87.8 \%$ following the addition of immobilized cells of Kluyveromyces marxianus. Similarly, the immobilized cells of Kluyveromyces marxianus can reduce levels of lactose in whey by up to $81.2 \%$ (Singh and Singh 2012). Immobilized cells exhibit many advantages over free cells, such as relative ease of product separation, reuse of biocatalysts, high volumetric productivity, improved process control and reduced susceptibility of cells on contamination (Goksungur and Zorlu 2001).

One of the most widely used matrices for cell immobilization is calcium alginate as a gel. It is widely used for whole cell entrapment due to its simplicity and non-toxic character. It has been applied for the immobilization of a large number of different types of cells such as bacteria, cyanobacteria, algae, fungi, yeast, plant protoplasts, and plant and animal cells (Goksungur and Zorlu 2001).

Lactobacillus plantarum strain B134 is a lactic acid baterium isolated from mustard greens fermentation whose $\beta$-galactosidase characteristics have been studied (Hartono 2013). The present study was intended to evaluate the effectiveness of immobilized $L$. plantarum B134 in hydrolysing lactose in UHT milk. 


\section{MATERIALS AND METHODS}

\section{Preparation of Lactobacillus plantarum strain B134 cell}

L. plantarum strain B134 was obtained from the Microbiology Culture Collection, LIPI, Cibinong, Indonesia. Firstly, the L.plantarum B134 cells were cultivated in MRS (de Man, Rogosa, Sharpe) medium for 18 hours at $37^{\circ} \mathrm{C}$. Cells were then harvested by centrifugation (KUBOTA 6500) at $9.500 \mathrm{rpm}$ using fixed angle rotor $\mathrm{AG}-2506,4^{\circ} \mathrm{C}$, for $15 \mathrm{~min}$. The pellet obtained was used for cell immobilization.

\section{Cell Immobilization}

Cell immobilization was carried out by firstly mixing cell suspensions and sodium alginate. The mixture was then transferred into a syringe. Gel beads were generated by dropping the mixture into a $50 \mathrm{~mL} \mathrm{CaCl}_{2}$ solution with stirring at $100 \mathrm{rpm}$, followed by incubation for 1 hour at $4^{\circ} \mathrm{C}$. Gel beads were filtered and washed with distilled water $3 \mathrm{x}$.

\section{Optimization of $\mathrm{CaCl}_{2}$ for cell immobilization}

To determine the optimum concentration of $\mathrm{CaCl}_{2}$ for cell immobilization, $\mathrm{CaCl}_{2}$ solutions of different concentration $(100 \mathrm{mM}, 300 \mathrm{mM}$ and $500 \mathrm{mM})$ were mixed with cells $(4 \% \mathrm{w} / \mathrm{v})$ and sodium alginate $(1 \% \mathrm{w} / \mathrm{v})$. Following the generation of cell beads, $\beta$-galactosidase activity of the immobilized cells was determined. Experiments were carried out in triplicate.

\section{Optimization of sodium alginate concen- tration for cell immobilization}

To determine the optimum concentration of sodium alginate for cell immobilization, sodium alginate solution of different concentrations
$(0.5 \% \mathrm{w} / \mathrm{v}, 1 \% \mathrm{w} / \mathrm{v}, 2 \% \mathrm{w} / \mathrm{v}$, and $3 \% \mathrm{w} / \mathrm{v})$ was mixed with cells $(4 \% \mathrm{w} / \mathrm{v})$ and $\mathrm{CaCl}_{2}(0.1 \%$ $\mathrm{w} / \mathrm{v})$. Following the generation of cell beads, $\beta$-galactosidase activity of the immobilized cells was determined. Experiments were carried out in triplicate.

\section{Optimization of cell concentration for cell immobilization}

To determine the optimum concentration of bacterial cells for cell immobilization, cells of different concentrations $(4 \% \mathrm{w} / \mathrm{v}, 8 \% \mathrm{w} / \mathrm{v}$, and $12 \% \mathrm{w} / \mathrm{v}$ ) were mixed with sodium alginate $(1 \% \mathrm{w} / \mathrm{v})$ and $\mathrm{CaCl}_{2}(0.1 \% \mathrm{w} / \mathrm{v})$. Following the generation of cell beads, $\beta$-galactosidase activity of the immobilized cells was determined. Experiments were carried out in triplicate.

\section{Determination of protein concentration}

Protein concentrations were determined by the Bradford method (1976), using bovine serum albumin as protein standard.

\section{Determination of $\beta$-galactosidase activity}

The $\beta$-galactosidase activity was determined by using the method of Liu et al (2009) with modification. $1 \mathrm{~mL}$ of $0.1 \mathrm{M}$ tris- $\mathrm{HCl} \mathrm{pH} 7.0$ buffer and cell beads were incubated at $37^{\circ} \mathrm{C}$ for 5 minutes. After the addition of $200 \mu \mathrm{L}$ of $o$-nitrophenyl-beta-dgalactopyranoside ( $o$-NPGal) $(2 \mathrm{mg} / \mathrm{mL})$, the mixture was incubated at the same condition for 5 minutes. To stop the reaction, $1 \mathrm{~mL}$ of $1 \mathrm{M}$ $\mathrm{Na}_{2} \mathrm{CO}_{3}$ was added. The amount $o$-nitrophenol $(o-\mathrm{NP})$ liberated as a product of hydrolysis was measured spectrophotometrically at a wavelength of $420 \mathrm{~nm}$. The optimum incubation time for $\beta$-galactosidase activity assay used in 
this study was determined by incubating the mixture for $0,5,10,15,20,25$, and 30 minutes folowed by determination of amounts of o-nitrophenol (o-NP) .

\section{Determination of effect of $\mathrm{pH}$ on $\beta$-galactosidase activity}

To determined the effects of $\mathrm{pH}$ on $\beta$-galactosidase activity, the $\beta$-galactosidase of the immobilized cells was assayed in a 100 $\mathrm{mM}$ Tris- $\mathrm{HCl}$ buffer solution with different $\mathrm{pH}$ values (5.0, 5.5, 6.0, 6.5, 7.0, 7.5, and 8.0). Experiments were carried out in triplicate.

\section{Determination of effect of temperature on $\beta$-galactosidase activity}

To determine the effects of temperature on $\beta$-galactosidase activity, the $\beta$-galactosidase activity of the immobilized cells was assayed in a $100 \mathrm{mM}$ Tris- $\mathrm{HCl}$ buffer solution at different temperature $\left(25^{\circ} \mathrm{C}\right.$, $30^{\circ} \mathrm{C}, 35^{\circ} \mathrm{C}, 40^{\circ} \mathrm{C}, 45^{\circ} \mathrm{C}, 50^{\circ} \mathrm{C}$, and $55^{\circ} \mathrm{C}$ ). Experiments were carried out in triplicate.

\section{Hydrolysis of lactose by immobilized cells in}

\section{a batch process}

To determine the efficiency of lactose hydrolyis by the immobilized cells, immobilized cells were added into $5 \mathrm{~mL}$ of UHT milk (skim and whole milk) as per Kishore and Kayastha 2012. The mixture was then incubated at $37^{\circ} \mathrm{C}$ for 24 hours. $250 \mu \mathrm{L}$ aliquots of sample was taken every 3 hours since the start of incubation. The concentration of the liberated glucose was estimated using the GOD-POD method. Experiments using free cells were carried as a control. Experiments were performed in duplicate. The percentage of the unhydrolysed lactose was calculated as:
$\%$ unhydrolysed lactose :

(glucose present without treatment with immobilized cells / glucose present after treatment with immobilized cells) x 100\%

A plot was generated with \% unhydrolysed lactose vs time

\section{Determination of glucose concentration}

Glucose concentrations were determined by using the GOD-POD kit. Milk samples were centrifuged at $10.000 \mathrm{rpm}$ (15880 g) for 5 minutes. The supernatants were collected for glucose assay.

\section{Determination of reusability of immobilized cells}

To determine the reusability of the immobilized cells, $5 \mathrm{~mL}$ of milk was mixed with immobilized cells. The mixture was incubated at $37^{\circ} \mathrm{C}$ for 12 hours when using UHT whole milk, and for 9 hours when using UHT skimmed milk, followed by determination of glucose concentration. The immobilized cells were then recovered by washing with distilled water and were used for the next batch. The immobilized cells were re-used by repeating the experiment for 4 batches.

\section{Statistical analysis}

Immobilization of Lactobacillus plantarum B134 cells used completely randomized design. The variables and their levels selected for obtaining immobilization were: $\mathrm{CaCl}_{2}$ concentration $(100 \mathrm{mM}, 300 \mathrm{mM}$, $500 \mathrm{mM})$, amount of sodium alginate $(0.5 \%$, $1 \%, 2 \%$, and $3 \% \mathrm{w} / \mathrm{v})$, amount of cell $(4 \%, 8 \%$, $12 \% \mathrm{w} / \mathrm{v}), \mathrm{pH}$ values $(5.0,5.5,6.0,6.5,7.0,7.5$, and 8.0$)$, temperature $\left(25^{\circ} \mathrm{C}, 30^{\circ} \mathrm{C}, 35^{\circ} \mathrm{C}, 40^{\circ} \mathrm{C}\right.$, $45^{\circ} \mathrm{C}, 50^{\circ} \mathrm{C}$, and $55^{\circ} \mathrm{C}$ ). Data were analyzed 
using SPSS 16.0. All experiments were done in triplicate and average of $o$-NP product obtained was taken as dependent variable or response (Y). The mathematical relationship relating the variables to the responses can be calculated by linier model equation (Ott 2001):

$Y_{\mathrm{ij}}=\mu+\tau_{i}+\varepsilon_{i j}$

Where $\mathrm{Y}_{\mathrm{ij}}$ is observation on $j$ th experimental unit receiving treatment $i, \mu$ is overall treatment mean, $\tau_{i}$ is an effect due to treatment $i,{ }^{\varepsilon_{i j}}$ is a random error associated with the response from the $j$ th experimental unit receiving treatment $i$. Statistical analysis of the model was performed to evaluate the analysis of variance (ANOVA) with $\alpha=0.05$. If the test result differs significantly then Duncan's test was done.

\section{RESULTS}

Optimal concentrations of $\mathrm{CaCl}_{2}$, sodium alginate, and culture cells, for cell immobilization.

Based on the amount of $o-\mathrm{NP}$ product generated following hydrolysis of $o$-NPGal substrate by immoblized cells of different
$\mathrm{CaCl}_{2}$ concentrations, it was found that the optimum concentration of $\mathrm{CaCl}_{2}$ for immobilization of L. plantarum B134 cells was $100 \mathrm{mM}$ (Fig 1). Similarly, the optimum concentrations of sodium alginate for cell immobilization was $1 \%$ (Fig 2), and the optimum cell concentration was 12\% (Fig 3).

\section{Optimum pH, temperature, and incubation} time for $\beta$-galactosidase assay.

Some factors such as $\mathrm{pH}$, temperature, and incubation time influence the $\beta$-galactosidase assay. Based on the amount of $o$-NP product released following hydrolysis of $o$-NPGal substrate by the $\beta$-galatosidase producingimmoblized cells, the optimum $\mathrm{pH}$, temperature, and incubation time for $\beta$-galactosidase assay was 6.5 (Fig 4), $45^{\circ} \mathrm{C}$ (Fig 5), and 5 min (Fig 6) respectively.

\section{Optimum incubation time for lactose hydrolysis}

The optimum incubation time for lactose hydrolysis was determined based on the percentage of the unhydrolysed lactose

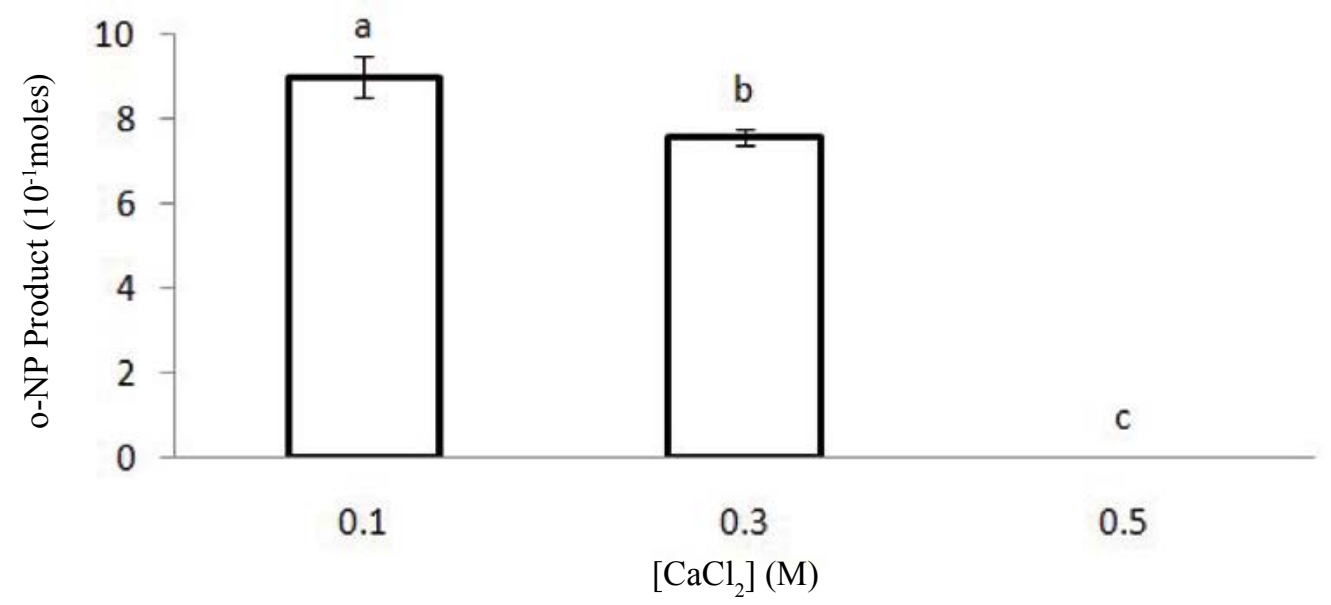

Figure 1 Amount of o-NP produce by L. plantarum $\mathrm{B} 134$ cell at various $\mathrm{CaCl}_{2}$ concentrations. Different letters showed data significantly different based on Duncan's test SPSS 16.0 software 


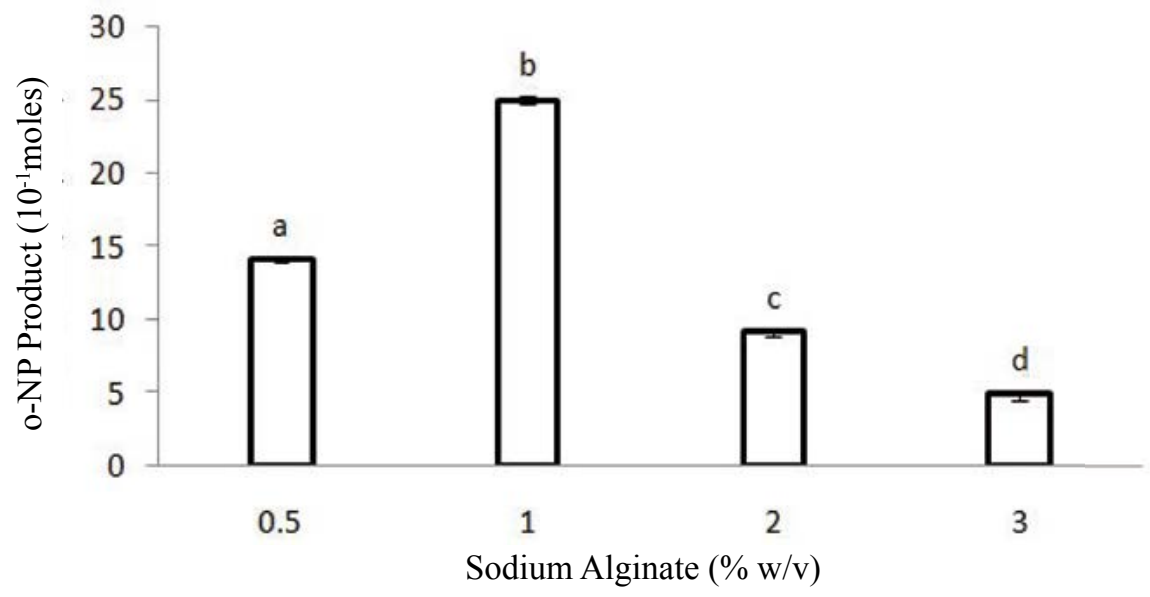

Figure 2 Amount of o-NP produce by L. plantarum B134 cells at various sodium alginate concentrations. Different letters showed data significantly different based on Duncan's test SPSS 16.0.

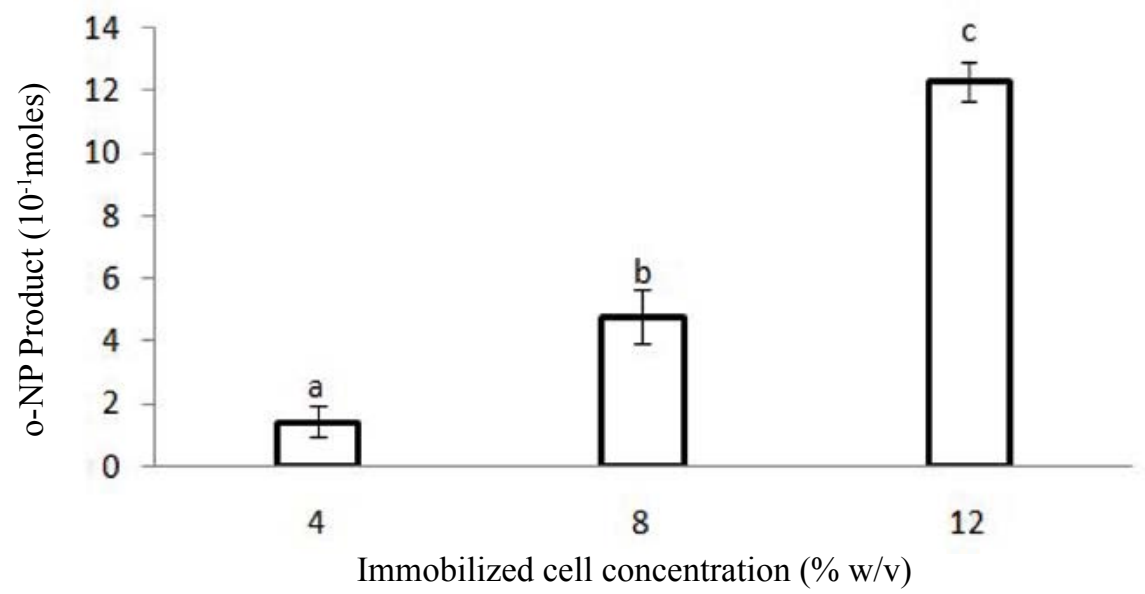

Figure 3 Amount of o-NP produced by L. plantarum B134 cells at various percentages of immobilized cells. Different letters showed data significantly different based on Duncan's test.

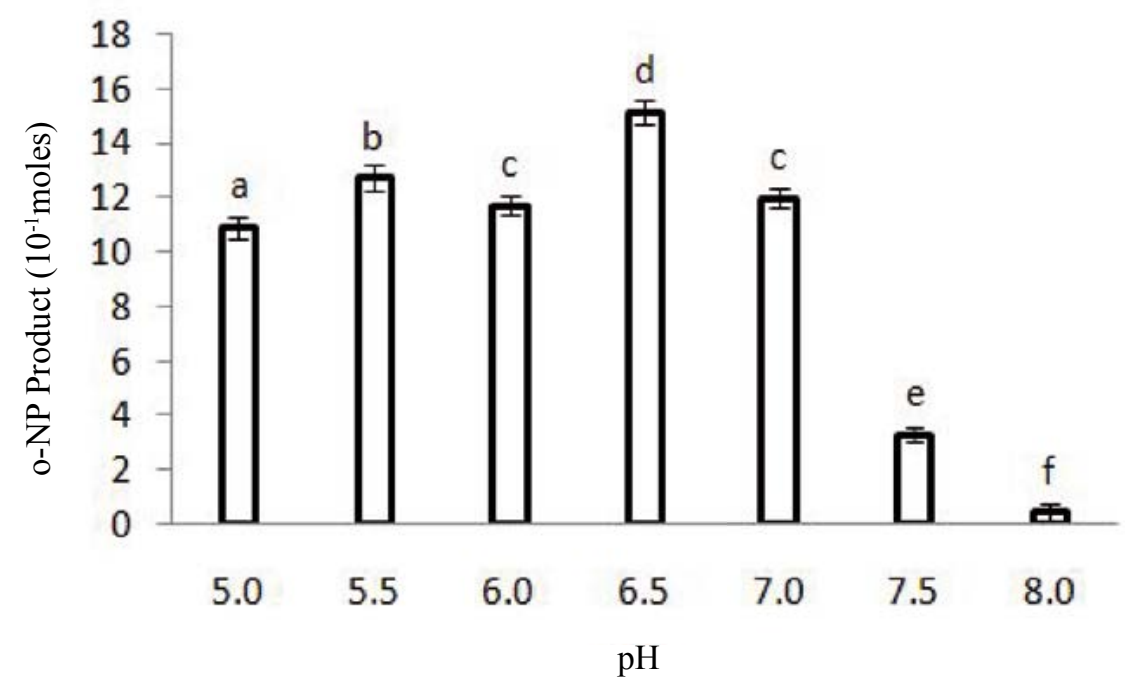

Figure 4 Amount of $o$-NP produced at various $\mathrm{pH}$ (immobilized cells). Different letters showed data significantly different based on Duncan's test. 
remaining following lactose degradation for various incubation times. The optimum incubation time for lactose hydrolysis of UHT whole milk by free and immobilzed cells were 6 $h$ and $12 \mathrm{~h}$, respectively (Fig 7). Likewise, the optimum incubation time for lactose hydrolysis of UHT skimmed milk by free and immobilzed cells were the same (9 h) (Fig 8).

The highest percentage of lactose hydrolysis in UHT whole milk using immobilized cells was $85.57 \%$ following incubation for 12 h. Similarly, the highest percentage of lactose hydrolysis in UHT skimmed milk was $92.38 \%$ following incubation with immobilized cells for $9 \mathrm{~h}$.

\section{Reusability of immobilized $L$. plantarum B134 cells}

In the present study, the immobilized cells were reused four times to hydrolyse lactose in UHT whole and UHT skimmed milk. The extent of reusability of the immobilized cells was determined based on their efficiency in hydrolysing lactose which was indicated by

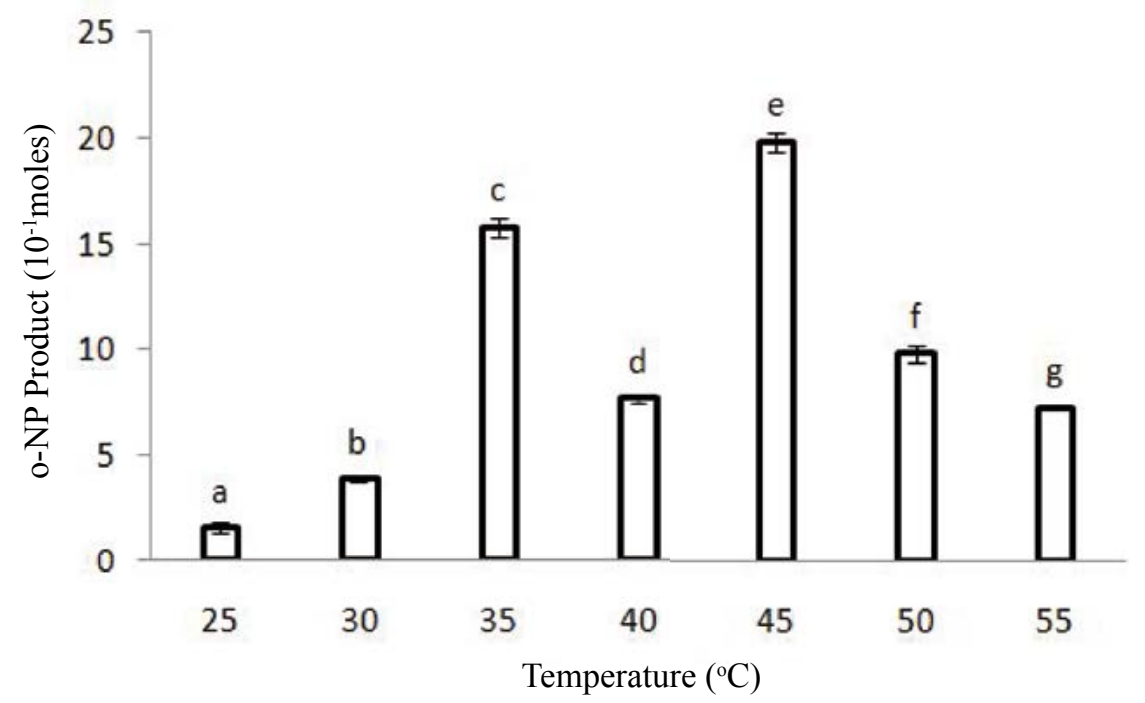

Figure 5 Amount of $o$-NP produced at various temperatures (immobilized cells). Different letters showed data significantly different based on Duncan's test.

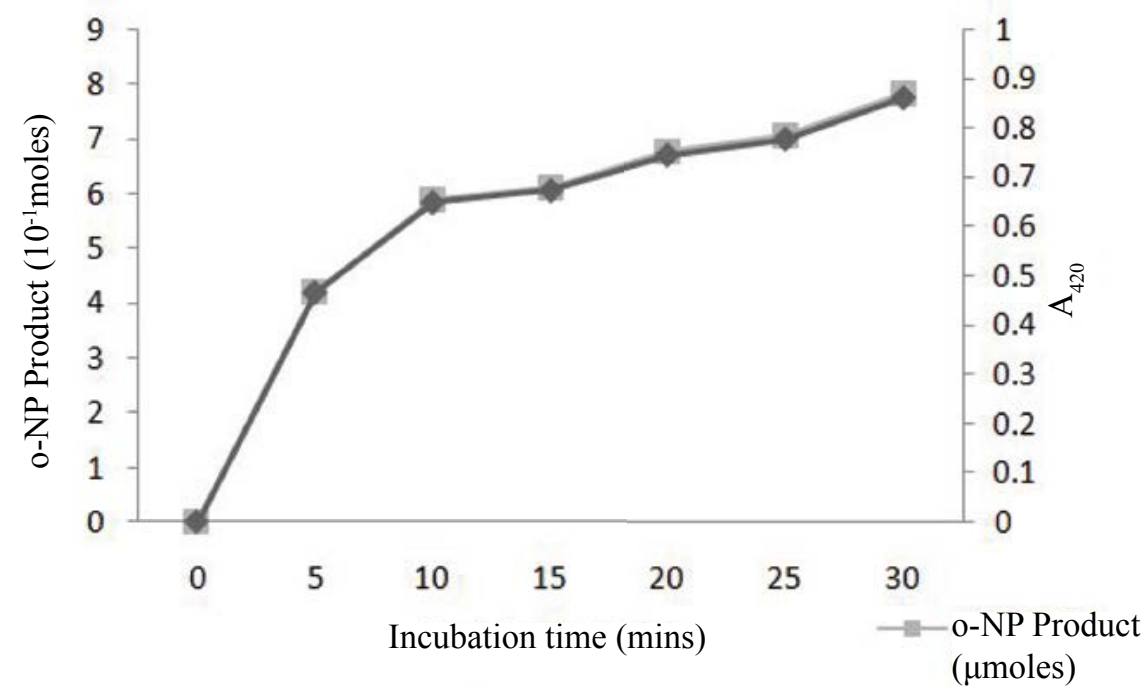

Figure $6 o$-NP product in various incubation times (immobilized cells). 


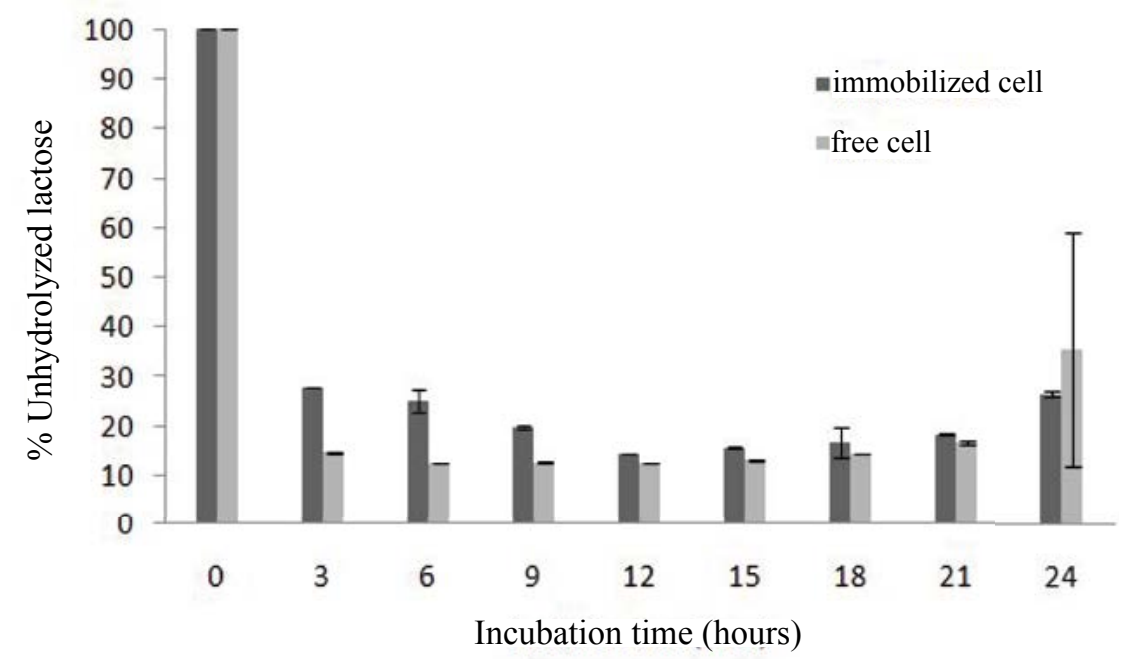

Figure 7 Amount of lactose remaining unhydrolyzed in UHT whole milk over various incubation periods.

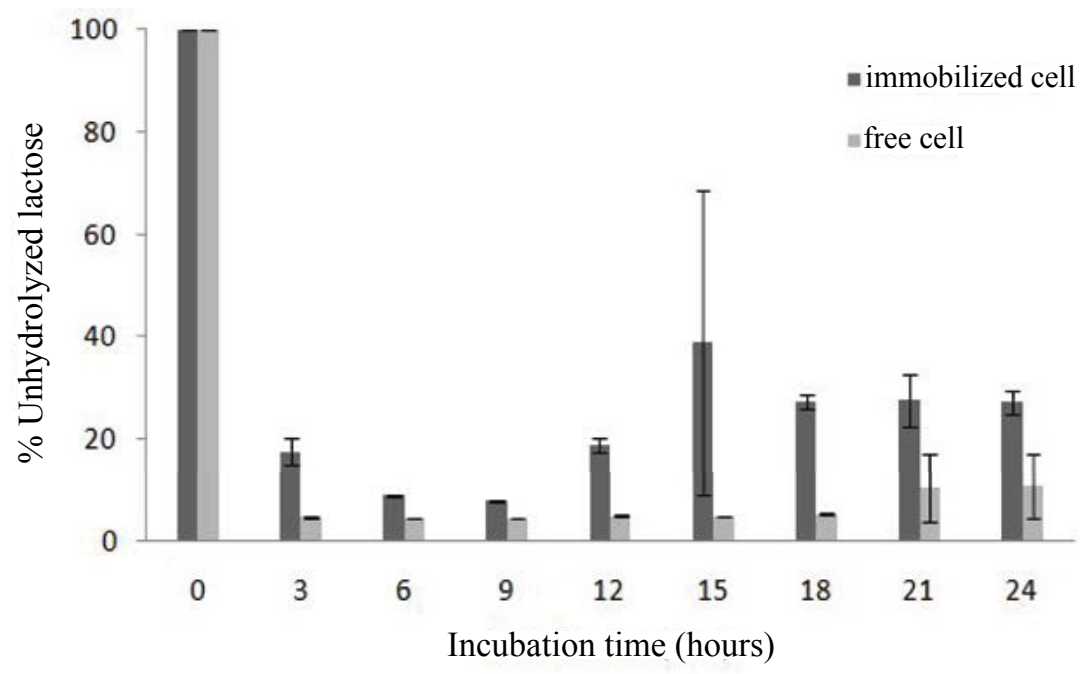

Figure 8 Amount of lactose remaining unhydrolyzed in UHT skimmed milk over various incubation periods.

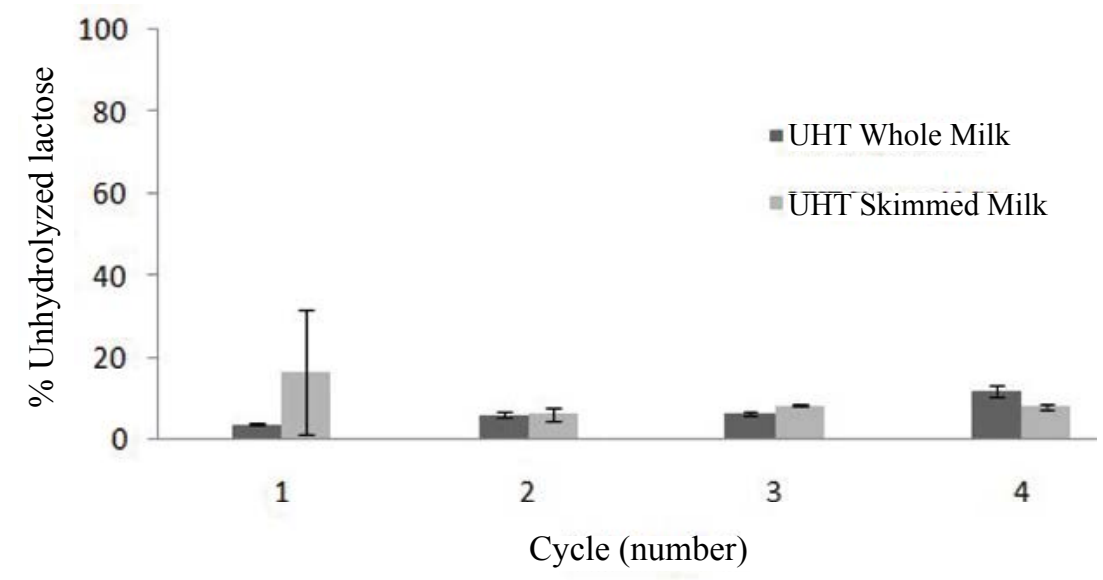

Figure 9 Reusability of immobilized cells. 
the percentage of the unhydrolysed lactose remaining following hydrolysis. Results showed that the immobilized cells can be used up to 4 times leaving $11.9 \%$ lactose residue in UHT whole milk and $7.6 \%$ lactose residue in UHT skimmed milk (Fig 9).

\section{DISCUSSION}

The shape and size of beads are both critical factors in cell immobilization. Encapsulation of cells in small size unit reduces the resistance of mass transfer caused by encapsulation materials. This condition can improve oxygen and nutrient availability for the cells located inside of the beads. Beads of the correct shape and uniform in size are important to ensure gelling uniformity and to avoid incomplete alginate gel formation (Keshaw et al. 2005).

L. plantarum B134 cells immobilized into an alginate matrix can be reused. In this technique cells are entrapped into a rigid matrix in order that the cell cannot break out the matrix while allowing lactose to enter the beads (Illanes et al 2008). A matrix is formed by $\mathrm{Ca}^{2+}$ cation reacts with the carboxylate anion of monovalent alginate. Alginate is a linear heteropolyshaccaride of D-manuronic acid and L-guluronate (Najafpour et al. 2004). Singh and Singh (2012) reported that Klyveromyces marxianus cell can be immobilized by using alginate matrix (5\% sodium alginate and 10\% $\mathrm{CaCl}_{2}$ ). Concentrations of sodium alginate which are too high can reduce the porosity of gel resulting in the cells being retained too rigidly in the gel. In this study, a $12 \%$ cell suspension of L. plantarum B134 can still be accommodated by an alginate matrix (Fig. 3).
Immobilization efficiency must be considered when immobilizing cells. An immobilization efficiency value can be used to evaluate the capacity of a matrix in entrapping cells (Worsfold 1995). In the present study, the immobilization effeciency of $L$. plantarum B134 cell was $28.95 \%$ based on assayable $\beta$-galactosidase activity. Ohmiya et al. (1977) reported that an immobilization efficiency of Lactobacillus bulgaricus, Escherichia coli, and Kluyveromyces lactis cells immobilized by using polyacrylamide gel was $27-61 \%$. Among these, the immobilization efficiency of Kluyveromycess lactis cells was the highest based on the level of $\beta$-galactosidase activity retained.

The $\beta$-galactosidase assay is influenced by $\mathrm{pH}$, temperature, and incubation time. Ionization conditions between enzyme-substrate are affected by $\mathrm{pH}$. At optimum $\mathrm{pH}$, ionization condition needs to be at the appropriate point making enzyme activity optimum (Nelson and Cox 2008). Meanwhile, temperature affects the collisions between substrate and enzyme molecules in the process of enzyme-substrate complex formation. The $\mathrm{pH}$ and temperature for an enzyme assay in immobilized cells is different from those for free cells because the matrix boundary makes the substrate difficult to to react with enzyme (Zhou and Chen 2001).

The color complex produced by $o-\mathrm{NP}$ can be measured using a spectrophotometer. Immobilzation of $E$. coli cells by sodium alginate converted $0.72-38.4 \mathrm{mM} o$-NPGal to $o$-NP. The $o$-NP product continues to increase until the substrate reaches $38.4 \mathrm{mM}$ (Yeon and Jung 2010). $\mathrm{K}_{\mathrm{M}}$ values for $\beta$-galactosidase in immobilized Lactobacillus bulgaricus, Escherichia coli, and 
Kluyveromyces lactis cells were $4.2 \mathrm{mM}, 5.4$ $\mathrm{mM}$, and $30 \mathrm{mM}$, respectively (Ohmiya et al. 1977). Banerjee et al. (1982) reported that $\mathrm{K}_{\mathrm{M}}$ value of $\beta$-galactosidase in immobilized- and free Saccharomyces anamensis cells were 148 $\mathrm{mM}$ and $102 \mathrm{mM}$, respectively.

Reeba et al. (2010) showed that milk hydrolysis using yeast cells entrapped in sodium alginate can hydrolyse lactose by up to $87 \%$. Decrease of lactose levels in skimmed milk reached $87.8 \%$ after the addition of immobilized Kluyveromyces marxianus cells (Panesar 2007). Meanwhile, immobilized cells of Kluyveromyces marxianus can reduce lactose in whey by $81.2 \%$ (Singh and Singh 2012). Mendoza et al. (2005) suggested to provide hydrolysis limit between 80 to $90 \%$ for the conversion of lactose in order to avoid excessive sweetness. The taste of skimmed milk after lactose hydrolysis by using $\beta$-galactosidase from Lactobacillus bugaricus, Esherichia coli, and Kluyveromyces lactis cells immobilized were almost the same (Ohmiya et al. 1997). Jokar and Karbassi (2011) showed that sensory evaluation of lactose-hydrolyzed milk and ordinary UHT milk (as the control) did not show any significant difference in acceptability of sweetness, taste, aftertaste, and color. Galactooligosaccharide (GOS) is one form of products that presence during lactose hydrolysis process. The GOS formed reached maximum about $10.000 \mathrm{mg} / \mathrm{L}$ when lactose hydrolysis in commercial UHT milk reached 75-90\% (Matute et al. 2012).

Immobilized cells can be used repeatedly. In this study, after the four time use, the activity of the immobilized cells decreased (Fig. 9). This can be caused by the fragile bead shape due to heat treatment and friction during the hydrolysis process, allowing cells to escape from the alginate matrix. Immobilized Saccharomycess anamensis cells could retain $\beta$-galactosidase activity up to $68.6 \%$ and could be stored at $4^{\circ} \mathrm{C}$ for 28 days (Banerjee et al. 1982). The reuse of immobilized cells can decrease activity during batch fermentation. For example, $\beta$-galactosidase activity of reused immobilized Escherichia coli cells was found to decrease. After the tenth use, the amount of a $\beta$-galactosidase activity level retained was only $20 \%$ of the initial value. The decrease in activity may be caused by washout of the cells from the alginate gel (Panek et al. 2012). Immobilized Kluyveromyces marxianus cells could be reused for up to eight cycles for carrying out lactose hydrolysis (Singh and Singh 2012).

\section{ACKNOWLEDGEMENT}

This research is part of PKPP LIPI RISTEK project. We are grateful to Research Center of Biology, Indonesia Institute of Science for providing funding support.

\section{REFERENCES}

[BPOM] Badan Pengawasan Obat dan Makanan. 2008. Kenali intoleransi lebih lanjut. InfoPOM Vol 9: 1-3.

Banerjee M, Chakrabarty A, Majumdar SK. 1982. Immobilization of yeast cells containing $\beta$-galactosidase. Biotech and Bioengineer 24: 1839-1850. doi: 10.1002/bit.260240810.

Bradford MM. 1976. A rapid and sensitive method for the quantitation of microgram quantities of protein utilizing the principle of proteindye binding. Analytical Biochem 72: 248254.

[FAO] Food and Agriculture Organization. 2006. Probiotics in food: Health and nutritional properties and guidelines for evaluation. Food and nutrition paper 85: 37-50. 
Goksungur Y, Zorlu N. 2001. Production of ethanol from beet molasses by $\mathrm{Ca}$-alginate immobilized yeast cell in a packed-bed bioreactor. Turk J Biol 25:265-275.

Grosova Z, Rosenberg M, Gdovin M, Slavikova L, Rebros M. 2009. Production of D-galactose using $\beta$-galactosidase and Saccharomyces cerevisiae entrapped in poly vinylalcohol) hydrogel. Food Chem 116: 96-100.

Hartono L K. 2013. Semipurifikasi dan karakterisasi $\beta$-galaktosidase dari isolat bakteri asam laktat strain B134. [Skripsi] Bogor: Institut Pertanian Bogor. Page: 6-10.

Illanes A, Fernandez LR, Guisan JM, Wilson L. 2008. Heterogeneous enzyme kinetics. In: Enzyme Biocatalysis Principle and Application. Chile: Spinger Science.

Jokar A, Karbassi A. 2011. In-house production lactose-hydrolysed milk by betagalactosidase from Lactobacillus bulgaricus. J. Agr. Sci. Tech 13: 577-584.

Keshaw H, Forbes A, Day RM. 2005. Release of angiogenic growth factors from cells encapsulates in alginate beads with bioactive glass. Biomaterials 26: 4171-4179.

Kishore D, Kayastha A M. 2012. Optimisation of immobilization condition for chick pea $\beta$-galactosidase ( $C p \mathrm{GAL})$ to alkylamine glass using respone surface methodology and its applications in lactose hydrolysis. Food Chem 134: 1650-1657.

Klein PM, Lucas PF, J'essie DNS, Marco AZA, Rafael CR, Jorge LN, Plinho FH. 2013. High stability of immobilized $\beta$-Dgalactosidase for lactose hydrolysis and galactooligosaccharides synthesis. Carbo. Polymers 95: 465-470.

Liu LL, Xiao M, Li ZY, Li YM, Wang FS. 2009. A Novel transglycosylating $\beta$-galactosidase from Lactobacillus Indigen B5. Pro. Biochem. 44: 232-236.

Makkar HPS, Sharma OP, Negi SS. 1981. Immobilization and properties of $\beta$-Dgalactosidase from Lactobacillus bulgaricus. J. Biosci. 3: 7-16.
Matute AIR, Martinez MC, Montilla A, Olano A, Copovi P, Corzo N. 2012. Presence of mono-, di-, and galactooligosaccharides in commercial lactose-free UHT diary products. J. Food Composition and Analysis 28(2): 164-169. doi: 10.1016/j.jfca.2012.06.003

Mendoza MR. Olano A., Villamiel M. 2005. Chemical indicators of heat treatment in fortified and special milks. J. Agric and Food Chem 53: 2995-2999.

Najafpour G, Younesi H, Ismail KSK. 2004. Ethanol fermentation in an immobilized cell reactor using Saccharomyces cerevisiae. Bioresource Tech 92: 251-260.

Nelson DL, Cox MM. 2008. Lehninger: Principles of biochemistry. $5^{\text {th }}$ Ed. New York: W.H Freeman and Company. Page: 207

Ohmiya K, Ohashi H, Kobayashi T, Shimizu S. 1977. Hydrolysis of lactose by immobilized microorganisms. Appl. Environ. Microbiol. 33: $137-146$.

Ott LR, Longnecker M. 2001. An introduction to statistical methods and data analysis. $5^{\text {th }} \mathrm{Ed}$. USA: Duxbury Thomson Learning. Page: 854-856.

Panek A, Pietrow O, Synowiecki J. 2012. Immobilized biocatalysts-useful tool for industrial process. PhD Interdiciplinary Jounal: 29-34.

Panesar PS. 2007. Lactose hydrolysis in whole milk using immobilized Kluyveromyces marxianus cells. Am. J. Food Tech. 2: 288294.

Panesar PS, Kumari S, Panesar R. 2010. Potential applications of immobilized $\beta$-galactosidase in food processing industries. Enz. Resch: 1-16. doi: $10.4061 / 2010 / 473137$

Reeba PS, Parmjit SR, Ram SS, Manav BB. 2010. Hydrolysis of milk lactose in a packed bed reactor system using immobilized yeast cells. J Chem Technol. Biotechnol 86: 42-46.

Singh A, Singh K. 2012. Study on hydrolysis of lactose in whey by use of immobilized enzyme technology for production of instant energy drink. Adv. J. Food Sci. Technol. 4:84-90. 
Sumathy R, Vijayalakshmi M, Deecaraman M. 2012. A study on $\beta$-galaktosidase of Lactobacillus sp. from milk product and its applications. Int. J. App. Biol. Pharm.Tech. 3: 138-148.

Wierzbicki LE, Kosikowski FV. 1973. Lactase potential of various microorganism grown in whey. J Dairy Sci 56: 26-29.

Worsfold PJ. 1995. Classification and chemical characteristics of immobilized enzymes. Pure \& Appl. Chem. 67:597-600.

Yeon JH, Jung KH. 2010. Operation of packed-bed immobilized cell reactor featuring active $\beta$-galactosidase inclusion body-containing recombinant Escherichia coli cells. Biotech. Bioprocess. Eng. 15: 822-829.

Zhou Q ZK, Chen XD. 2001. Effect of temperature and $\mathrm{pH}$ on the catalytic activity of the immobilized $\beta$-galactosidase from Kluyveromyces lactis. Biochem. Eng. J. 9: 33-40. 